DOI 10.14746/ssp.2018.3.3

Jakub JAKUBOWSKI

Adam Mickiewicz University in Poznań

\title{
Intercultural competences and social media: contribution through research
}

\begin{abstract}
Intercultural research in the area of communication was initiated in the early 20th century. Over the last few decades, researchers have built a solid theoretical basis in this field. Nowadays, intercultural analyses include a rich collection of texts on cross-cultural differences, the specificity of the phenomenon in the area of verbal and non-verbal communication and also the role of the media. There is no doubt that in an era of dynamic transformations of media use by people all over the world, the sub-discipline of intercultural communication is facing another challenge - that of including social media and network communication processes into new empirical theories and research. The article answers the question of the status of communication research in the field of the intercultural contexts of the new media. Additionally, the directions of future development of these studies and conclusions are discussed.
\end{abstract}

Key words: intercultural competences, intercultural communication, social media, third culture model

\section{Introduction}

$\mathbf{I}$ $\mathrm{t}$ is a well-known fact that the media have changed dynamically in the last few years. In a world where multimedia devices have become the 'first screen' for almost all people in their twenties or thirties throughout the European Union, a new way of looking at interculturalism should be considered (Mobile). Nowadays, we know a lot about the traditional media (papers, radio, TV) and their influence on the process of intercultural communication. After decades of media research, it is obvious that this impact is generally positive in the majority of cases. Thanks to the media, people can find out new facts about other cultures, learn foreign languages, observe lifestyles and understand certain cultural dimensions, such as different definitions of time and space (Marchis, Ciascai, Saial, 2008). On the other hand, the visible problem of traditional media in many countries 
is stereotyping people, or ignoring facts related to the culture of the society they operate in. ${ }^{1}$

Despite the fact that media researchers should continue to examine these phenomena, they also ought to (and they do!) direct their attention to the new ways of communication predominantly used by young people. The Internet, which is an international, open media structure, seems to be a natural and obvious environment for intercultural contacts. Therefore, it seems to be related to young people, mobility and innovative ways of gaining new communication skills. Interculturalism and media research is moving in richly varied directions. One of the most dynamic fields of this research can be found in new media studies.

\section{The role of new media in monitoring of intercultural issues}

To discuss this topic, it is necessary to explain the meaning of interculturalism. Two important elements of this cultural and social process can be found. One is related to the communication and academic component - this is the way people from different cultures communicate with each other (intercultural or cross-cultural communication; Allwood, 1985). To be more precise, this aspect of interculturalism consists of those processes which make different cultures closer, especially in the field of relations and communication between individuals. Additionally, the condition of respect for cultural diversity is also taken into account.

The other element is ideological - interculturalism is the idea of supporting intercultural programs, skill sharing and cross-cultural dialogue. It refers to the support for challenging auto-segregation tendencies within ethnic groups. Interculturalism promotes moving beyond the passive acceptance of the fact of diversity of cultures peacefully existing in a society, and involves relations and interaction between cultures (Penas, López Sáenz, 2006, p. 15). In this sense, this phenomenon is more an individual attitude than a social fact.

Media research makes it possible to diagnose many aspects of the latter sense of interculturalism. The basis of these surveys is web content, which is provided by Internet users. Unlike with traditional media, texts, pictures and movies in their social counterparts are created and put online

${ }^{1}$ There are dozens of pieces of research in the field of ethnic and racial discrimination, gender studies and others in different types of media (Zhang, 2005; Crawford, 1998; Hoffmann, 1991; Mou, Peng, 2009 and many others). 
by users themselves. One of the many consequences of this trend is delivering thoughts, attitudes and opinions (big data), which can be analyzed and may tell us a lot about our local, national or European societies. By means of web content analysis, we can examine the field of interculturalism for the following, among other things:

- How popular are intercultural ideas, programs, political decisions, etc.?

- What do people think about intercultural facts? What are their expectations (e.g. the migration problem)?

- How does the process of communication between people take place (use of arguments, populism, etc.)?

- What is the intensity of discussion on the new media (disputes, positive or negative emotions related to some topics)?

To put it bluntly, it is possible to download and analyze everything that people express online by text or - sometimes - through pictures and movies. We can measure these kinds of communication processes using a wide range of digital methods. The characteristic thing about this kind of research is working with 'big data' - a huge body of texts, pictures and videos, which can be collected and analyzed. Needless to say, it is not feasible for media researchers to classify them manually. Researchers need to have a tool to collect, verify and filter out of big data those elements that are useful to analyze. ${ }^{2}$ Thanks to the enormous quantity of data that is produced by net users every single day (In $2015 \ldots$...), we can conjecture that topics related to interculturalism are very popular across blogs, e-mails and social media users. Media researchers are increasingly interested in monitoring these trends.

The Erasmus Plus Program is probably the best example of interculturalism based on the promotion of the intercultural idea in Europe. Nowadays, it is quite easy to check the context of the discussion about this program being held by net users. The analysis mentioned below is social media monitoring research conducted with the support of selected $\mathrm{SaS}$ (Software as a Service). In Figure 1, a fragment of the report is presented.

${ }^{2}$ There are two ways to perform this task. Firstly, a special algorithm can be written by the researchers themselves. This is probably the most accurate way to prepare a research program, because a special tool can be designed to obtain the precise information that is needed. The second option is using an external or commercial tool, which is easy to use and gives far more opportunities than other solutions. 
Figure 1. Internet users` communication activity about the Erasmus Plus Program

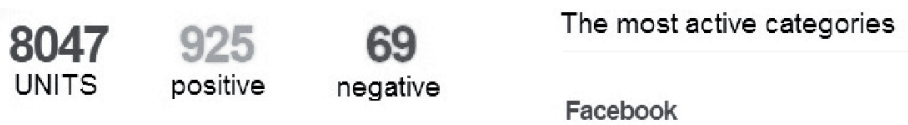

3801

The most active pages

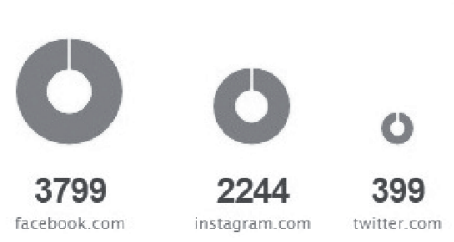

Photo

2245

Others

1153

Results

Attitude
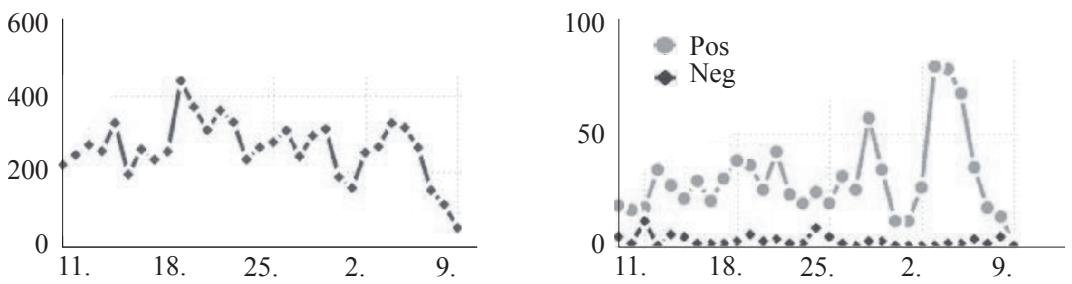

Source: Brand24, 9. May 2016.

The results show how many people used the phrase Erasmus in the media during 30 days between April 10 and May 10, and what the reach of this topic was (data was collected from websites in Polish). Further, we can observe the most popular communication channels where this phrase was used. It is also easy to check people's attitudes to this subject, which allows us to answer many questions. According to this data, social media monitoring tools may be very useful to check the discussion of problems devoted to interculturalism. The potential of these tools is huge. They are often called another pair of eyes that let us see much more than when reading social media in the traditional manner. What seems to be clear is that they can generally be useful for media and culture researchers; thanks to these tools they are able to gain knowledge helpful in improving programs and promoting intercultural ideas in a more effective way. But, on the other hand, they might also be important for students who want to gain knowledge about certain intercultural 
issues. Therefore, they can be used to examine intercultural differences in media communication styles, the popularity of topics abroad, preparation for foreign travel, etc. Most commercial or open-access software can be used for free, or as a free trial option. A list of the most popular programs for collecting and analyzing new media content can be found in the presentation. ${ }^{3}$

\section{Social media and homogenization of cultures}

The second trend of new media and intercultural competences research involves the question of whether we are dealing with a new culture and a new competence of intercultural online communication that we need to learn. The most important question in this case reads as follows: is there any special code or style of communication which is universal for people all over the world? Therefore, media researchers try to find a counterpart of the emotions expressed in 'face to face communication' like anger or happiness (Ekman, 1978). Comparative methods in linguistics, sociology and anthropology are used to find similarities in the online communication habits of web users from different cultural fields (Kulturkreis). Something which is quite obvious today, as Soliz and Pfister mentioned, is that "there are new 'spaces' of international communication based on images and text" (Pfister, Soliz, 2011, p. 246). Thus, images and text are universal for all of us as a form or pattern of communication, regardless of our affiliation to cultural circles. But it is only the first step in the discussion about the universal character of online communication. A useful theory that may explain this problem is the third culture model. "Casmir conceptualized the framework as an active process whereby different cultural groups come together to form a third culture between them. The third culture then becomes a common ground for all participants; a cognitive space that incorporates elements of both cultures and yet remains separate and distinct" (Hopson, Hart, Bell, 2012). As visualized in Figure 2, this model originally did not apply to media use (Arbel), but it can be successfully adapted to the new media reality.

3 The most popular of them are: Sprout Social, Hootsuite, Synthesio, Brandwatch Analytics, Crimson Hexagon, Talkwalker, Klear, Mention, Brand24, Buffer (Behr, Marvin). 
Figure 2. Third Culture Model

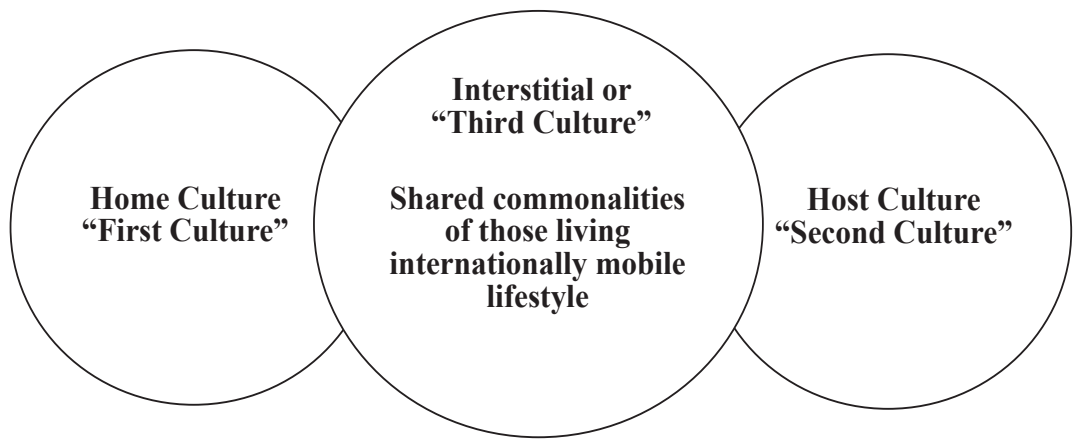

Source: Third.

It is worth mentioning that a third culture is not exactly a mixture of two or more cultures, but provides a kind of a new value - in our example - new ways of communication based on the dominant culture model. Clothier called this "the hybrid virtual culture," believing that a hybridized cultural identity can emerge from being inducted into a virtual community. It is composed of diverse people and cultural influences that border and overlap each other. Theoretically, hybrid virtual cultures and hybrid identities are antagonistic to authority and cultural hegemony, according to Clothier (2005, pp. 44-59). Chen and Dai add that because the West dominates cyberspace in so many significant ways - linguistically through the English language, symbolically via the West's pervasive icons, and materially, in Western created hardware and software - it is unclear whether hybrid cultural identities are, indeed, possible and whether identity co-creation and negotiation can truly occur in virtual communities consisting of disparate, unrelated individuals (Chen, Dai, 2012, pp. 123-138; Shuter, 2012, pp. 222).

A vivid way of explaining this issue is provided by the standards of social media communication. This kind of online information exchange is based on a 'many to many' dialogue. In practice, it is usually a specific mixture of texts, pictures, movies, links, etc. One of the most basic elements of this communication model is comments, which are an indispensable part of the dialogue between social media users. If someone uses, say, Facebook, they probably know that the form of text must be attractive to the communications receiver to become widely-read. Therefore, media users apply various 'tricks' to make a comment attractive. If we 
want to say that 'someone did something really great' it can be done in several ways: by text, by emoticons or by a more elaborate combination of information consisting of pictures, cultural contexts, other media genres, etc. This is called 'memetic communication' and it seems to be, on the one hand, the most grueling, but on the other - the most effective.

One may ask why net users make use of this option, which is - to be honest - a fairly time-consuming and complicated way of interacting? First of all, it appears to be visually attractive. Secondly, which is much more important, it is culturally universal and based on popular culture (Brooks, 2014), which becomes a new communication platform, wellknown to Internet users, especially those who use web devices as 'the first screen' (iGeneration). Therefore, the knowledge of new media use seems to be a new intercultural competence, which eases communication between people from all over the world. Thanks to the fact that it goes beyond national languages, it is becoming a new, universal space of communication. What is more, there are many proofs nowadays that social media are becoming a platform that is similar to the third culture model.

\section{Social media as a platform for research and externalizing of cultural differences}

The reverse situation is the externalizing of cultural differences via social media. After a decade of web 2.0 technologies, it is quite obvious that many differences in the online communication of people from different countries can be found. Thanks to the globalization process, in communication styles, too, it is necessary for net users to learn new codes which appear to be universal. However, it needs to be underlined that it is impossible to change all the cultural habits that are inherent parts of our identity. Patterns of media use are also small pieces of this identity. Online communication is quite similar to its offline counterpart in this field. For instance, gestures are a universal element of body language, but the same movement may signify something offensive or nice in different countries and cultures (Özüorçun, 2013, p. 72). Nowadays, media researchers try to observe these differences, especially using behavioral methods. To be precise it is worth explaining how our culture affects our communication with others via Facebook, Twitter, etc. As we know, there are a few fields of externalizing these differences. G. M. Chen concludes by his research that cultural identity influences the way of using elec- 
tronic media at the levels of thinking patterns, expressing oneself and cultural contexts (Chen, 2000). It is also visible in the cultural dimensions described by Edward Hall, Geert Hofstede and others (Hall, 1976; Hofstede, 2001; Hofstede, Hofstede, 2005).

According to Derek Lackaff, people from individualistic cultures using low-context communication techniques are more likely to express more information about themselves on social media (Rosen, Stefanone, Lackaff). In an attempt to prove this thesis, in 2010, Kim, Sohn and Choi compared the media behavior of students from totally different cultures: South Korea and the United States. They found a correlation between the content that young Internet users produced and the communication styles that they used. As the authors showed, students from South Korea prefer to express their social relations by texting, posting pictures of their friends and other web content. Students from the United States more often published elements showing entertainment on their social media profiles, like parties, meetings, etc. (Kim, Sohn, Choi, 2011, pp. 365-372). This is one of many proofs that people transpose some communication styles from offline onto virtual reality, and the computer screen does not constitute a barrier to this transfer. This also suggests an appropriate course of action in building new cultural competences to make our communication with people from other countries more understood, also by the new media.

\section{Correlation between media use and cultural competence}

Looking back to the above examples, a more general question can be asked: do social media have a positive impact on our cultural competence or not? Undoubtedly, the above-mentioned trends in research show some kind of correlation between media use and cultural competence. Therefore, it seems to be the most general and well-proven direction of media research in the field of intercultural communication. Despite the fact that this correlation can be found in the previous examples, this subject deserves a bit of attention.

During the last few decades, thanks to using behavioral research methods and investigating traditional and new media, it is possible to conclude in general that media use has a positive impact on the process of acculturation (Sawyer). What is more, the longer we integrate with different cultures, the more often we use local media, which affects the acculturation process in a positive way. Needless to say, this is a generalization, 
and dependent variables may change the results of specific research, but the role of the media is usually positive. Thanks to them, learning new languages is made possible and more effective. Media also give a great opportunity to acquire knowledge about a new place of living, a local society, local mores, codes of conduct, etc. Thus, media use may be helpful in preventing culture shock, bringing people forward in the adaptation process and being a tool for entering into contact with other people.

To illustrate this thesis, examples catalogued by Shuter were chosen (2012, p. 222): "Chun (2011) found that on-line contact between Germans and American university students learning one another's languages significantly increased their cultural awareness and intercultural communication skills. Belz (2005) reported that internet-mediated language learning between Germans and Americans dramatically improved the participants' ability to use questions to ascertain cultural information, which they argue is an essential component of intercultural competence. While investigating the effect of blogs on second language learning for Spanish and American students, Elola and Oskoz (2008) discovered that blogging in newly acquired languages improved both groups' intercultural competence [...]. Diehl and Prins (2008) found that Second Life enhanced the participants' 'intercultural literacy' by promoting intercultural friendships, second language acquisition, and openness to diverse cultures, practices, and attitudes." These few examples (there are many more instantiations in this case) prove that new media are a very promising platform in supporting the process of learning intercultural competence. Using new media intentionally and including them in our cultural experience may be very useful for people who study, work or stay in a multicultural environment.

\section{New media as a tool of reintegration}

Observing the political and ethnic situation in the Old Continent nowadays, one of the most important questions from the European and presentday point of view is the role of the new media in the integration/reintegration process. This new trend in media studies may be seen as an exception to the rule mentioned in the above examples. In the last few years, media researchers found, especially in Europe, some conditions that may be problematic for shaping modern and open societies. This problem may become a burning issue in the immediate future, owing to the new wave 
of immigrants and their desire (or lack of desire) to improve their cultural skills. For several years, media researchers have tried to verify this thesis by behavioral research methods or case studies. The key question here is: are there any special media habits of people living in non-original cultures? It is symptomatic that the latest studies show the new media as a frequent tool of reintegration with the ethnic culture in the second generation, in contrast to the first generation, which is more willing to use the media of their new place of living. In some cases, it may enrich their cultural competence by new knowledge about their ethnic roots. But, on the other hand, it might be dangerous for the integration process.

One of the most crucial examples of this trend is given by Steven Croucher. He showed that French Muslims visit Islamic social media more often than local pages, which can be problematic for the acculturation process, and more a way of rebuilding their Muslim identity (Shuter, 2012, p. 222; Croucher, 2011, pp. 259-264). What is more, it may be a part of the process of reintegration: immuring themselves in and starting to use new cultural codes. Therefore, in this case, the most important fact is not the possibility of finding content that may be improper, offensive and against European values. The problem is that this kind of media use may be a source of negation in the field of communication as well. Interestingly, similar processes were also found in Korea and Australia.

\section{Recommendations}

Considering several examples of relations between the media and intercultural skills, some recommendations premised on them can be made. First of all, social media research tools may be a useful instrument for monitoring programs, ideas, topics, etc. related to interculturalism (1). If we want to know what people think about certain crucial problems, we do not need to ask them directly nowadays. It may also be done by monitoring what people tweet, or write on their 'walls.' While one person is perhaps not enough to draw some conclusions, hundreds make a difference.

What is more, knowledge of the 'online language' is one of the most important intercultural competences nowadays (2). In this case, 'online language' is understood as a group of communicative intercultural competences which are universal for the 'third' or online culture. Therefore, to understand what people want to tell us by text, picture, movie or sound, we need to follow the modern ways of using new media. 
Studying social media content is crucial to understand differences in communication styles (3). It is obvious that direct contact with another person (face to face communication) is still the basic way of learning new skills. But considering how many hours per day people use social media to communicate with other people (in Europe it is about two hours a day or more), it appears to have become an extremely important part of our intercultural life. This is worth remembering when people try to learn about new places and cultures. Therefore, the new media may be a very effective platform for teaching cultural competences (4) but on the other hand, in some cases, social media may be a tool of reintegration (5). It is necessary to remember that social media are not only an opportunity for improving some social skills but also a threat, which is not less important when faced with so many problems in Europe in recent years.

\section{Bibliography}

Allwood J. (1985), Intercultural Communication, "Papers in Anthropological Linguistics", vol. 12.

Brooks A. (2014), Popular Culture: Global Intercultural Perspectives, New York.

Casmir F. L. (1978), Intercultural and international communication, Washington.

Casmir F. L. (1997), Ethics in intercultural and international communication, Mahwah.

Chen G. M. (2000), Global communication via Internet: An educational application, in: Communication and global society, eds. G. M. Chen, W. J. Starosta, New York.

Chen G. M., Dai X-d. (2012), New media and asymmetry in cultural identity negotiation, in: New media and intercultural communication: Identity, community and politics, eds. P. H. Cheong, J. N. Martin, L. Macfadyen, New York.

Chen W. (2010), Internet-usage patterns of immigrants in the process of intercultural adaptation, "Cyberpsychology, Behavior, and Social Networking," vol. 13.

Chun D. M. (2011), Developing intercultural communicative competence through online exchanges. "CALICO Journal," vol. 28.

Clothier I. M. (2010), Created identities: Hybrid cultures and the internet, "Convergence: The Journal of Research into New Media Technologies," vol. 11(4).

Croucher S. M. (2011), Social networking and cultural adaptation: A theoretical model, "Journal of International and Intercultural Communication," vol. 4.

Croucher S. M., Cronn-Mills D. (2011), Religious misperceptions: The case of Muslims and Christians in France and Britain, New York.

Ekman P., Friesen W. (1978), Facial Action Coding System: A Technique for the Measurement of Facial Movement, Palo Alto. 
Hall E. T. (1976), Beyond Culture, Anchor Books.

Hoffmann G. (1991), Racial Stereotyping in the News: Some General Semantics Alternatives, "ETC: A Review of General Semantics," vol. 48.

Hofstede G. (2001), Culture's Consequences: comparing values, behaviors, institutions, and organizations across nations (2nd ed.), Thousand Oaks.

Hofstede G., Hofstede J. (2005), Cultures and organizations: software of the mind (Revised and expanded 2 nd ed.), New York.

Hopkins L. (2008), Muslim Turks and anti-Muslim discourse: The effects of media constructions of 'Islamic' and 'Arabic' in Australia, "Australian Journal of Communication," vol. 35.

Hopson M., Hart T. B., Bell G. C. (2012), Meeting in the middle: Fred L. Casmir's contributions to the field of intercultural communication, "Communication Studies."

Kim Y. Y. (1988), Communication and cross-cultural adaptation: An integrative theory, Philadelphia.

Kim Y. Y. (2001), Becoming intercultural: An integrative theory of communication and cross-cultural adaptation, Thousand Oaks.

Kim Y., Sohn D., Choi S. M. (2001), Cultural difference in motivations for using social network sites: A comparative study of American and Korean college students, "Computers in Human Behavior," vol. 27(1).

Marchis I., Ciascai L., Saial J. (2008), Developing Intercultural Competencies Using Activities with Different Media, "Acta Didactica Napocensia," vol. 1.

Mou Y., Peng W. (2009), Gender and Racial Stereotypes in Popular Video Games, in: Handbook of Research on Effective Electronic Gaming in Education, Concordia.

Oh D. (2012), Mediating the boundaries: Second-generation Korean American adolescents' use of transnational Korean media as markers of social boundaries, "International Communication Gazette," vol. 74.

Özüorçun F. (2013), The importance of body language in intercultural communications, "EUL Journal of Social Sciences."

Penas I. B., López Sáenz M. C. (2006), Interculturalism: Between Identity and Diversity, Bern.

Pfister D. S., Soliz J. (2011), (Re)Conceptualizing Intercultural Communication in a Networked Society, "Journal of International and Intercultural Communication."

Shuter R. (2012), Intercultural New Media Studies: The Next Frontier in Intercultural Communication, "Journal of Intercultural Communication Research."

Soliz J., Pfister D. S. (2011), (Re)Conceptualizing Intercultural Communication in a Networked Society, "Journal of International and Intercultural Communication," vol. 4.

Zhang Y. (2005), Stereotypes of and Discrimination Against Racial/Ethnic Minorities: Can Media Exposure Help Change People's Racial/Ethnic Prejudice for the Better or for the Worse?, Washington. 


\section{Internet Resources}

ArbelN.,ThirdCultureKids,https://spinstrangenesscharm.wordpress.com/2010/11/27/ third-culture-kids/.

Behr A., Marvin R., The Best Social Media Management \& Analytics Tools of 2016, http://www.pcmag.com/article2/0,2817,2491376,00.asp.

Crawford J., Media, Stereotypes and the Perpetuation of Racism in Canada, Occasional Papers in Educational Technology (University of Saskatchewan, May 1998), http://etad.usask.ca/802papers/crawford/crawford.PDF.

In 20152.5 Quintillion bytes of data are created every day, http://www.vcloudnews. com/every-day-big-data-statistics-2-5-quintillion-bytes-of-data-created-dai$1 \mathrm{y} /$.

Mobile Is the New First Screen, https:/www.oracle.com/assets/mobile-infographic-2595872.pdf.

Sawyer R., The Impact of New Social Media on Intercultural Adaptation, http:// digitalcommons.uri.edu/cgi/viewcontent.cgi?article=1230\&context=srhonor sprog.

Rosen D., Stefanone M. A., Lackaff D., Online and offline social networks: Investigating culturally-specific behavior and satisfaction, http://www.informatik. uni-trier.de/ ley/db/conf/hicss/hicss2010.html.

\section{Kompetencje interkulturowe i media społecznościowe: przyczynek do badań}

\section{Streszczenie}

Zainicjowane w początkach XX w. badania interkulturowe w obszarze komunikacji przez ostatnie dziesięciolecia zbudowały solidną podstawę teoretyczną. Stanowi ona dzisiaj bogaty zbiór tekstów dotyczących różnic międzykulturowych, specyfiki zjawiska w obszarze komunikacji werbalnej i niewerbalnej, ale i roli mediów w tym procederze. Nie ulega wątpliwości, iż w dobie dynamicznych przeobrażeń w dziedzinie korzystania z mediów przez ludzi niemal we wszystkich zakątkach świata, przed subdyscypliną komunikacji międzykulturowej stoi kolejne wyzwanie - włączenie mediów społecznościowych i procesów komunikacji sieciowej w ramy nowych teorii i badań empirycznych. Artykuł odpowiada na pytanie: na jakim etapie znajduje się nauka o komunikowaniu w obszarze badań interkulturowych kontekstów nowych mediów? Jednocześnie opisane są kierunki rozwoju niniejszych badań oraz wnioski $\mathrm{z}$ nich płynące.

Słowa kluczowe: kompetencje interkulturowe, komunikacja interkulturowa, media społecznościowe, model trzeciej kultury 
